\title{
The Prevalence of Musculoskeletal Disorders among Orthopaedic and Traumatology Residents in Indonesia
}

\author{
Romy Deviandri*, Yoyos Dias Ismiarto
}

\begin{abstract}
ABSTRAK
Gangguan muskuloskeletal sangat sering terjadi pada residen orthopedi. Penelitian ini bertujuan untuk menggambarkan jenis gangguan muskulosketal pada residen orthopedi di rumah sakit Hasak Sadikin, Bandung. Penelitian ini merupakan suatu survei deskriptif-analitik pada semua residen orthopedi di kota Bandung dengan jumlah total subjek 56 orang. Hasil penelitian menunjukkan bahwa prevalensi gangguan muskuloskeletal terbanyak terdapat pada area punggung bawah (50\%), diikuti pada leher (46,5\%), pergelangan tangan (28,6\%), pergelangan kaki $(28,6 \%)$, bahu $(21,4 \%)$, lutut $(10,7 \%)$, paha dan bokong $(10,7 \%)$, punggung atas $(7,1 \%)$, dan siku $(0 \%)$. Kesimpulan penelitian ini, nyeri punggung bawah serta nyeri leher merupakan gangguan muskuloskeletal tersering pada residen orthopedi. Oleh karena itu, diperlukan strategi efektif untuk mencegah terjadinya gangguan ini pada populasi residen orthopedi.
\end{abstract}

Keywords: LBP, low back pain, neck pain, ergonomic, an orthopedic resident

Musculoskeletal disorders have been common in the last few decades. The factors of continuous work and maintaining the body in not ergonomic position often cause interference with the muscles that are used predominantly in work, for example, on the shoulders, neck, back, wrists, and lower back.

Low back pain (LBP) is one of the widely complained in the community. It was estimated that $60-85 \%$ of the world's entire population had experienced LBP during his lifetime ${ }^{1}$. The annual prevalence of LBP was reported as $15-45 \%{ }^{2}$. The highest incidence of low back pain is found at the age of 35-55 years, and there was no difference in the incidence between men and women ${ }^{3}$. At a young age below 45 years, LBP was most often caused by mechanical factors related to work $^{2,4}$. Besides LBP, musculoskeletal disorders influence the neck, wrists, shoulders, upper back, thighs,

\footnotetext{
* Corresponding author: romydeviandri@lecturer.unri.ac.id

1 Department of Physiology, Medical Faculty of Universitas Riau/ Division of Orthopedic and Traumatology, Arifin Achmad Hospital, Pekanbaru, Indonesia

2 Department of Orthopedic and Traumatology, Medical Faculty of Universitas Padjadjaran/ Hasan Sadikin Hospital, Bandung, Indonesia
}

or ankles depending on the predominant muscles involved in excessive work activity ${ }^{5}$.

An orthopedic resident is one of the resident groups with the highest mobility. In a day, the average orthopedic resident does work with a minimum duration of 8 hours with various body positions while working. An orthopedic resident does a lot of twisting, bending, rotation, or lifting heavy loads while doing his work. This is not following the principle of ergonomics, "fitting the task for the human." The movements that are not ergonomic will cause mechanical disruption to the anatomic structure, resulting in musculoskeletal disorders. ${ }^{6,7}$

The high rates of musculoskeletal injury among hard workers have been previously recognized in the literature. However, there is a lack of data regarding musculoskeletal symptoms among resident orthopedic surgeons in Indonesia.

\section{METHODS}

This was a descriptive-analytic study with the subjects included all orthopedic and traumatology residents at Hasan Sadikin Hospital period 2012 to 2016 with the criteria: 
a. The subject was still registered as an orthopedic resident at RSHS in 2016

b. Has been a resident $>6$ month

The materials used in this study are:

1) Nordic Questionnaire

2) Informed consent of the following research.

After the consent was given, the survey was conducted by asking orthopedic residents of Hasan Sadikin Hospital in Bandung to fill out the Nordic questionnaire (figure 1) to determine the prevalence of musculoskeletal disorders (Part 1). The Nordic questionnaire was repeated after one week to measure the reliability of the questionnaire (Part 2). Reliability represents the extent to which individuals can be distinguished from each other despite measurement errors. Reliability was assessed in terms of test-retest reliability. The test-retest reliability concerns the extent to which patients' scores are the same for repeated measurements. ${ }^{8}$ To explore test-retest reliability, participants were asked to complete the Nordic questionnaire again after one week. To determine whether health status and function remained indeed stable between completion of parts 1 and 2, patients were explicitly asked at the start of the part 2 questionnaire, "Has your status changed since filling out the initial questionnaire?". The three possible responses were (1) no; (2) yes, the problem changed for the better; and (3) yes, the problem changed for the worse. Only patients indicating no change in their body function compared with the initial questionnaire were included in the test-retest analysis.

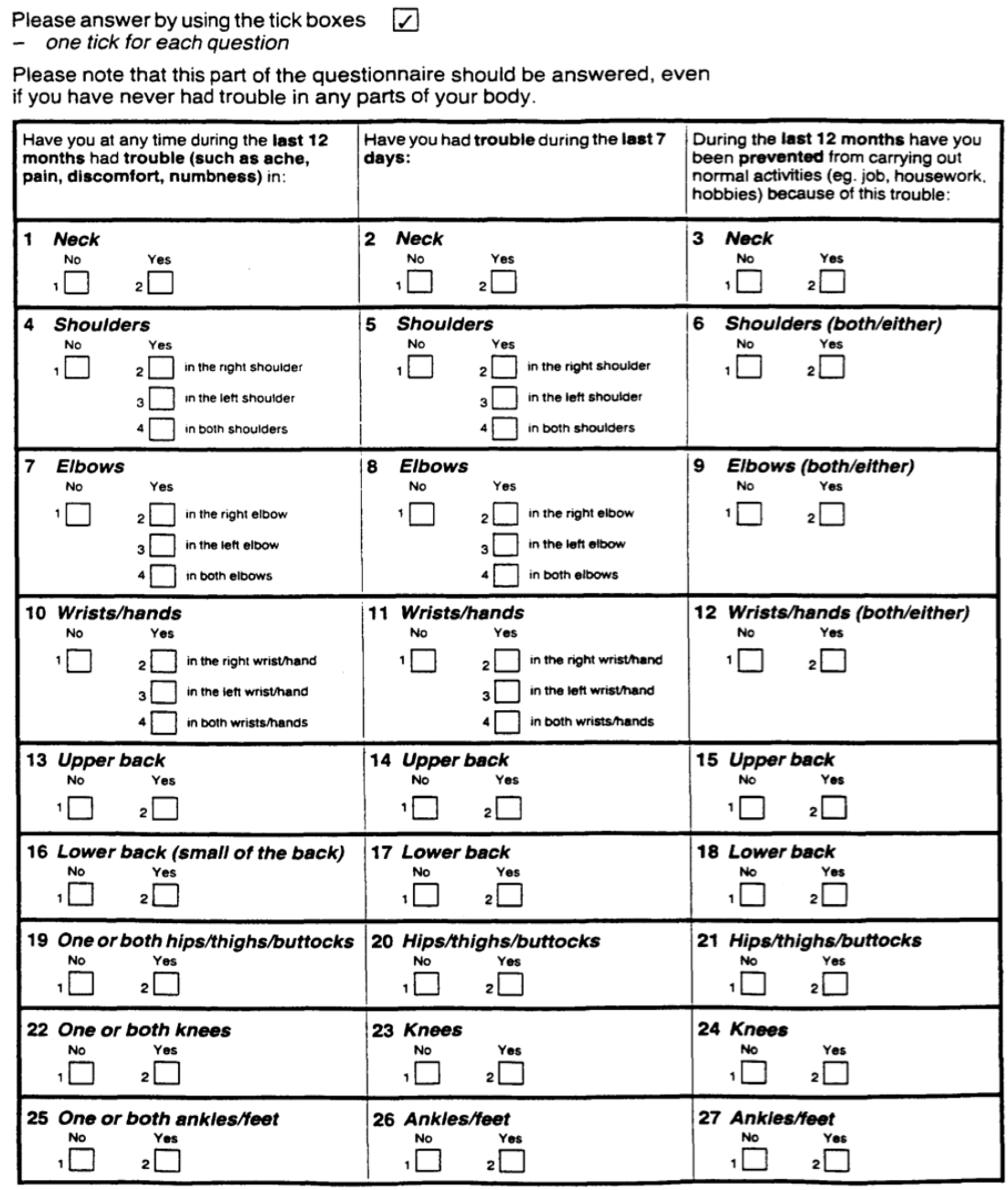

Figure 2 Musculoskeletal questionnaire

Figure 1. Nordic questionnaire ${ }^{4}$ 
Data from the filling out of the questionnaire will be processed in the form of a table to determine the distribution of data and a description of the prevalence of musculoskeletal disorders that occur among orthopedic residents. To assess reliability, the kappa statistic $(\mathrm{k})$ was measured. The percent observed agreement between repeated survey items $\left(\mathrm{P}_{0}\right)$ and the kappa statistic $(\mathrm{k})$ were calculated for each survey item. The statistics were then stratified and compiled by question type and reported for each type of question..$^{9,10}$

\section{RESULTS}

This study was conducted in the period 1-30 April 2016 by taking samples from orthopedic and traumatology residents in Hasan Sadikin Hospital consisting of 56 people, with 52 males $(93 \%)$ and four females $(7 \%)$. No patients reported better or worse health and function when they filled out the Part 2 questionnaire. None of the patients were excluded because of missing data. The mean age of subjects was 31 years with an age range of 26-40 years. The mean duration of work was 12 hours per day with a description of work as a surgery operator of 1.3 hours, as operating assistant 3.67 hours, and others including inpatient visits, outpatient clinic, resident self-study, and sports exercise were 7 hours. The prevalence of disorders experienced by orthopedic and traumatology residents was described in table 1 . That table showed that the highest prevalence of pain disorder was low back pain (46.4\% of males and $3.6 \%$ of females), followed by neck pain $(42.9 \%$ of males and $3.6 \%$ of females).

Table 1. The prevalence of the musculoskeletal disorder

\begin{tabular}{llcc}
\hline Description & Sex & Number & Percentage \\
\hline \multirow{2}{*}{ Neck pain } & Male & 24 & 42.9 \\
& Female & 2 & 3.6 \\
\multirow{2}{*}{ Shoulder Pain } & Male & 12 & 21.4 \\
& Female & 0 & 0 \\
\hline \multirow{2}{*}{ Wrist pain } & Male & 16 & 28.6 \\
& Female & 0 & 0 \\
\multirow{2}{*}{ Upper back pain } & Male & 4 & 7.1 \\
& Female & 0 & 0 \\
\multirow{2}{*}{ Elbow pain } & Male & 0 & 0 \\
& Female & 0 & 0 \\
\multirow{2}{*}{ Low back pain } & Male & 26 & 46.4 \\
\multirow{2}{*}{ Thigh and buttock pain } & Female & 2 & 3.6 \\
\hline \multirow{2}{*}{ Knee pain } & Male & 6 & 10.7 \\
\hline \multirow{2}{*}{ Ankle and foot pain } & Female & 0 & 0 \\
\hline
\end{tabular}

\section{Reliability}

The calculated kappa statistic for each repeated type of survey question was positive, indicating the presence of agreement between repeated administrations of the survey across all compiled question types. The kappa values in all repeated survey items more than $0.8(\mathrm{k}>0.8)$ showed almost perfect agreement according to benchmarks proposed by Landis and Koch. ${ }^{11}$

\section{DISCUSSION}

Thephysicaldemandsandhighmusculoskeletal injury rates among practicing orthopedic surgeons have been previously recognized in the literature. ${ }^{8}$ It has been known there was a strong association of physical and psychosocial factors with the musculoskeletal symptoms in surgeons. This study found that the highest prevalence of pain disorder of orthopedic and traumatology residents was low back pain (46.4\% of males and $3.6 \%$ of females), 
followed by neck pain (42.9\% of males and $3.6 \%$ of females).

Orthopedic surgeons spend much of their working hours in ergonomically challenging postures. Furthermore, they often work in a static position for a long duration. Fixed posts are required to maintain a stable position for as long as the period of surgery. In addition, during surgery, the body position often bends more than 20 degrees, twisting and lifting surgical instruments and parts of the body such as when operating femur, tibia, and other limbs. However, holding this position for long-duration could result in pain, especially in the part of the body that is higher involved, such as the lower back and neck muscles. ${ }^{6,7}$ It could be worse by movements in a not-ergonomic position. This results in line with Yassi\&Lochart (2013) described that health worker activities conferred an increased risk for and were associated with back disorders. ${ }^{11}$ In addition, Knudsen et al. showed that in the resident surgeons, the most common self-reported symptoms reported in the neck (59\%), lower back (55\%), upper back (35\%), and shoulders (34\%). ${ }^{12}$

Musculoskeletal disorders are related to the type of work and posture position while doing work. For orthopedic residents, bad posture while working tends to experience musculoskeletal disorders, especially in the lower back and neck region. Furthermore, the workstyle score was significantly associated with the symptom severity, especially in the low back part. ${ }^{13}$ Therefore, more attention needs to be paid to the ergonomic and physical environments in which we are training the next generation of orthopedic surgeons, especially when considering the extensive societal investment in training for these specialists.

However, a threshold of orthopedic resident activities below the risk of neck and back disorders has not been established and needs further investigation.

\section{CONCLUSION}

Low back pain and neck pain are the most musculoskeletal disorders among residents of orthopedic and traumatology. Therefore, it is necessary to take steps and approaches in order to minimize the incidence of low back pain and neck pain in this population.

\section{REFERENCES}

1. Lotters F, BurdorfA, Kuiper J, Miedema H. Model for work-relatedness of low back pain. Scand J Work Environ Health. 2003;29(6):431-440.

2. Hills, Everett C. Mechanical Low Back Pain. Emedicine, cited at March 30, 2020. Available from URL: https://emedicine.medscape.com/ article/310353-overview.

3. Maher CG. Effective physical treatment for chronic low back pain. Orthop Clin North Am. 2004; 35(1), 57-64.

4. Crawford J. O. The Nordic Musculoskeletal Questionnaire. Occupational Medicine J. 2007;57(4); 300-1.

5. Apley. A.G, Solomon. L. Apley's System of Orthopaedics and Fracture- $9^{\text {th }}$ Edition. London. Hachette UK Company. 2010

6. Scheer S J, Mital A. Ergonomics (Focused review). Arch Phys Med Rehabil 1997;78:36-45

7. Hodler J, Schulthess GK von, Zollikofer CHL, Musculoskeletal Disease, Diagnostic Imaging and Interventional Technique. Italy, Springer Verlag. 2005

8. Terwee CB, Bot SD, de Boer MR. Quality criteria were proposed for measurement properties of health status questionnaires. J Clin Epidemiol. 2007;60(1):34-42.

9. Hoehler FK. Bias and prevalence effects on kappa viewed in terms of sensitivity and specificity. $\mathrm{J}$ Clin Epidemiol. 2000;53(5):499-503.

10.Landis JR, Koch GG. The measurement of observer agreement for categorical data. Biometrics. 1977;33(1):159-74

11. Yassi A, Lockhart K. Work-relatedness of low back pain in nursing personnel: a systematic review. Int J Occup Environ Health. 2013 JulSep;19(3):223-44.

12.Knudsen ML, Ludewig PM, Braman JP. Musculoskeletal pain in resident orthopedic surgeons: results of a novel survey. Iowa Orthop J. 2014;34:190-6.

13. Szeto GP, Ho P, Ting AC, Poon JT, Cheng SW, Tsang RC. Work-related musculoskeletal symptoms in surgeons. J Occup Rehabil. 2009 Jun;19(2):175-84. 